\title{
Combination of LNT and SCR for NO reduction in passenger car applications
}

\begin{abstract}
The removal of $N O$ and particulate emissions in light-duty diesel vehicles will require the use of aftertreatment methods like Diesel Particulate Filters (DPF) and Selective Catalytic Reduction (SCR) with urea and Lean NO Trap (LNT) (Euro 6 and beyond). A new concept is the combination of LNT $+S C R$, which enables on-board synthesis of ammonia $\left(\mathrm{NH}_{3}\right)$, which reacts with NOx on the SCR catalyst. The main application for this kind system will be lighter passenger cars, where LNTs may be used instead of full urea-SCR system. That particular combinatory system was investigated by developing platinum (Pt) and rhodium (Rh) containing LNTs and SCR catalysts in this study. In the use conditions, the maximum temperature may reach temperatures up to $800^{\circ} \mathrm{C}$ and $\mathrm{NOx}$ reduction reactions should proceed without $\mathrm{NO}_{2}$ assistance in the SCR position after LNT and DPF. PtRh/LNT with the total loadings of $85 \mathrm{~g} / \mathrm{cft}(2.8 \mathrm{~g} / \mathrm{L})$ and higher resulted in a high $N O$ efficiency above $80-90 \%$ with a broad operation window in the laboratory simulations. In the experimental conditions, a higher $\mathrm{NH}_{3}$ concentration after LNT was essential to simulate well the operation of SCR catalysts. The developed $\mathrm{Cu}$-SCR catalyst showed a high hydrothermal durability up to the ageing temperature of $800{ }^{\circ} \mathrm{C}$ and a wide operation window without the $N O$, assistance (NO only in feed). Fe-SCR and V-SCR catalysts were more dependent on $\mathrm{NO}_{2}$. A studied concept had an air injection after LNT to keep SCR condition always in lean side, where the $S C R$ reaction was promoted by oxygen resulting in high reduction selectivity to nitrogen $\left(\mathrm{N}_{2}\right)$ without $\mathrm{NH}_{3}$ emissions. The simulations in reaction conditions and system design resulted in the proposals for the optimal design and main reaction mechanism in DOC $+D P F+L N T+S C R$ systems.
\end{abstract}

Key words: $N O_{x}, S C R, L N T$, catalysts, diesel

\section{Introduction}

Fuel consumption $\left(\mathrm{CO}_{2}\right.$, price) has become a driving force in engine and vehicle development. A low fuel consumption of diesel engines has resulted in their wide use also in light-duty applications, even if the fuel economy savings are increasing as a function of the weight of vehicle [1]. Efficient and economic $\mathrm{NO}_{\mathrm{x}}$ and $\mathrm{PM}$ (particulate matter) removal methods are the main challenges of future aftertreatment systems (ATS) for diesel engines. The demand for the simultaneous fuel consumption $\left(\mathrm{CO}_{2}\right)$ and emission decrease limits the possibilities to apply many of developed ATSs.

The selective catalytic reduction (SCR) of $\mathrm{NO}_{\mathrm{x}}$ by urea on sulfur-tolerant vanadium-SCR or thermally stable zeoliteSCR catalysts has been applied commercially world-widely. Urea is the source for ammonia, which selectively reacts with NO forming nitrogen $\left(\mathrm{N}_{2}\right)$ in lean exhaust gases. The SCR reactions are promoted at low temperatures by $\mathrm{NO}_{2}$ formed on diesel oxidation catalysts (DOC). The exhaust gas recirculation (EGR) in diesel engines decreases $\mathrm{NO}_{\mathrm{x}}$ emissions by decreasing combustion temperatures with the costs higher PM emissions. Urea-SCR for light-duty vehicles has limitations in urban driving conditions, where exhaust gas temperatures are below $200{ }^{\circ} \mathrm{C}$ [2]. An external heating of the SCR system is a method to maintain conditions in SCR window $\left(>200^{\circ} \mathrm{C}\right)$ in urban driving or light-off region [3]. Urea/ $\mathrm{NH}_{3}-\mathrm{SCR}$ is thus a very selective and efficient method but it requires urea solution stored in the vehicle and injection systems. Ammonia formation by urea hydrolysis has also limited rate (evaporation, thermolysis, hydrolysis and deposits) at low temperatures.

Lean $\mathrm{NO}_{\mathrm{x}}$ traps (LNT) have been also applied for $\mathrm{NO}_{\mathrm{x}}$ removal particularly in light-duty applications, where the required periodic enrichments $(\lambda<1)$ are not able to harm the fuel economy with the same magnitude like in heavy-duty applications. However, the injected fuel forms reductants for
$\mathrm{NO}_{\mathrm{x}}$ and no additional reductant tanks are needed. $\mathrm{NO}_{\mathrm{x}}$ is first adsorbed in lean on alkali or earth alkaline metals (like barium) as nitrates, which are then reduced to nitrogen during short rich peaks (for $2-5 \mathrm{~s}$ at $1-3 \mathrm{~min}$ intervals). Precious group metals (PGM, like platinum and rhodium) as active metals are necessary to form efficiently $\mathrm{NO}_{2}$ in lean and to catalyze $\mathrm{NO}$ reduction during rich periods. The $\mathrm{NO}_{\mathrm{x}}$ adsorption sites adsorb efficiently also almost all $\mathrm{SO}_{x}$ in exhaust gas, which results in the known S-poisoning (sulfation) of LNT. Sulfur regeneration in longer rich periods above $600^{\circ} \mathrm{C}$ regenerates LNT back to active state to adsorb again $\mathrm{NO}_{\mathrm{x}}$. The periodic rich peaks for nitrate and sulfate regeneration increase the fuel consumption up to $10 \%$ compared to fully lean diesel combustion. However, the longer rich peaks result in the risk of $\mathrm{NH}_{3}$ emissions. Control strategies for LNT regeneration have been tailored to avoid these drawbacks but the prevention of harmful side product formation limits also the possible $\mathrm{NO}_{\mathrm{x}}$ reduction capacity.

The combinatory properties have been applied in new systems utilizing ammonia, formed on LNT, downstream on SCR catalyst [4-6]. $\mathrm{NH}_{3}$ formed during rich periods are stored on the SCR catalyst where it subsequently reacts with $\mathrm{NO}_{\mathrm{x}}$ passing LNT [6]. Copper $(\mathrm{Cu})$ and iron $(\mathrm{Fe})$ zeolites have been mainly used as SCR catalysts due to high thermal durability requirements $\left(>700^{\circ} \mathrm{C}\right)$. The high ammonia adsorption capacity is important for the SCR catalyst to maximize the $\mathrm{NH}_{3}$ buffer for lean $\mathrm{NH}_{3}$-SCR. The use of reformer unit and by-pass for LNT may enhance the LNT regeneration [7]. Fuel is converted in a reformer to $\mathrm{CO}$ and hydrogen which are more efficient, final reductants for $\mathrm{NO}_{x}$. Periodic enrichments on LNT during the by-pass flow makes possible to have engine independent LNT regeneration (no need for engine throttling to reach $\lambda$ values below 1 in LNT). A key question is also the order of LNT and DPF in final systems. The regeneration and thermal management 
of the upstream unit is much easier than the downstream unit. Because both DPF and LNT units are large ( $>$ engine volume), it is difficult to heat up efficiently the either unit in the downstream position.

The LNT based systems are compared by the order of units and LNT regeneration strategies (Fig. 1). LNT may be also is in close-coupled position before the diesel particulate filter (DPF) in systems A-C. That set-up improves the low temperature $\mathrm{NO}_{x}$ performance of LNT but limits DPF regeneration. LNT can be coated on DPF structure, which is also a commercial solution and integrates PM filtration and $\mathrm{NO}_{\mathrm{x}}$ removal by LNT (8). The LNT regeneration varies and can be based on engine enrichment (fuel), throttling and/or introduced reformer gas.
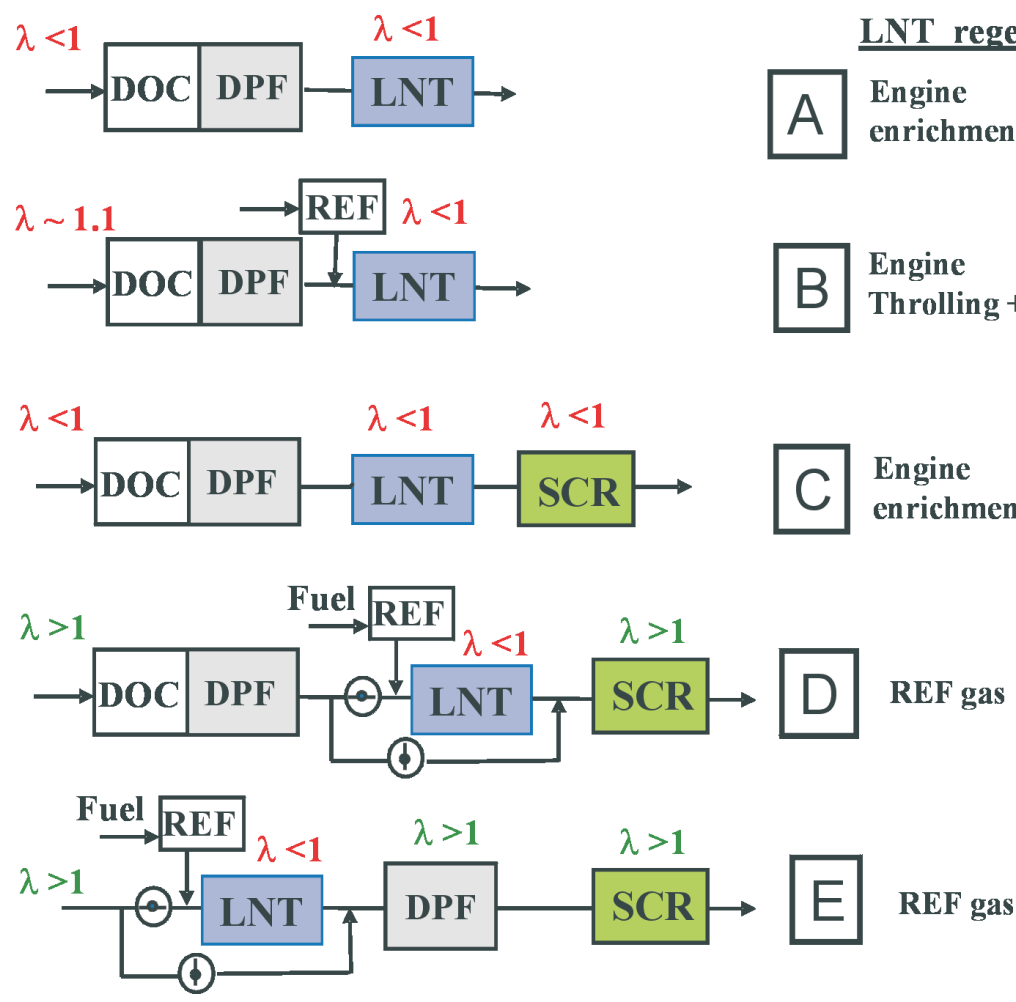

Fig. 1. LNT and LNT + SCR configurations together with DOC + DPF for diesel applications. The shown $\lambda$ values are related to the LNT regeneration period [9]. REF $=$ Reformer

Carbon (soot) accumulated in DPF is oxidized by short active regeneration periods (1-2 min by the interval of about few hundreds kilometers) at temperatures above $600^{\circ} \mathrm{C}$ or passively by the $\mathrm{NO}_{2}$ assistance in normal driving conditions when the exhaust temperature is above $250{ }^{\circ} \mathrm{C}$. The DPF regeneration (max. $700-800^{\circ} \mathrm{C}$ ) causes the main thermal durability requirements for LNT and SCR catalysts in these kinds of systems.

In our studies, the development of LNT and SCR catalysts were summarized and optimized for the combinations of LNT and SCR. The reaction studies were a tool to interpret key reaction paths in this combinatory system. The laboratory simulations were targeting to develop the full-scale catalysts to be applied in FEV, VKA and VW in the same work package in this EU funded Powerful project.

\section{Experimental and methods}

\subsection{Catalysts}

The LNTs in the experiments were based on metal substrates $(500 \mathrm{cpsi}$, foil thickness $50 \mu \mathrm{m})$, where an alumina based porous coating (about $150 \mathrm{~g} / \mathrm{L}$ ), active metal and $\mathrm{NO}_{\mathrm{x}}$ trap compounds were added. Thermally stable rare earth element (REE, e.g. Ce) based oxygen storage and thermal stabilizer material were added as promoters for LNT. Platinum and rhodium were impregnated on catalysts resulting in an even noble metal dispersion on washcoat [10]. Finally, the samples were dried and calcinated at $550{ }^{\circ} \mathrm{C}$ in air. The surface area (BET) of LNT coating was between about $130-140 \mathrm{~m}^{2} / \mathrm{g}$.

SCR catalysts were also based on metallic substrates

Engine en richment/throlling

LNT regeneration:

Engine en richment/throlling

Engine Throlling + REF gas F gas heated by conventional resistance or fast IR furnaces, where the diameter of samples was $14 \mathrm{~mm}$. The compositions of exhaust gases were analyzed by FID ( $\mathrm{HC})$, IR ( $\left.\mathrm{CO}, \mathrm{CO}_{2}\right)$, chemiluminescence $\left(\mathrm{NO}_{\mathrm{x}}, \mathrm{NO}, \mathrm{NO}_{2}\right.$ ) and FTIR (e.g. $\mathrm{NH}_{3}, \mathrm{~N}_{2} \mathrm{O}$, individual $\mathrm{HCs})$.

The activity of samples were measured in laboratory experiments, where a cycle includes longer lean and short rich periods simulating conditions in LNT and LNT + SCR systems. The lean-rich cycles were repeated for five times with these mixtures (Table 1). The feed gas composition simulated common lean exhaust gas analyzed with diesel engines. The absence of $\mathrm{NO}_{2}$ simulated the $\mathrm{D}$ or $\mathrm{F}$ systems (no DOC + DPF before LNT). A light hydrocarbon, propene was the only $\mathrm{HC}$ in the feed gas to make the fast variation 
of the inlet composition possible in transient condition. The total flow rate was $5.3 \mathrm{~L} / \mathrm{min}$.

Table 1. Experimental conditions in laboratory simulations

\begin{tabular}{|l|c|c|c|}
\hline Mixture & Lean & Rich & Rich + air \\
\hline $\mathrm{NO}_{x}, \mathrm{ppm}$ & 500 & 1500 & 1065 \\
\hline $\mathrm{C}_{3} \mathrm{H}_{6}, \%$ & 0.1 & 0.1 & 0.07 \\
\hline $\mathrm{CO}, \%$ & 0.25 & 5.73 & 4.07 \\
\hline $\mathrm{H}_{2}, \%$ & 0.08 & 2.0 & 1.42 \\
\hline $\mathrm{CO}_{2}, \%$ & 10 & 10 & 7.1 \\
\hline $\mathrm{H}_{2} \mathrm{O}, \%$ & 10 & 10 & 7.1 \\
\hline $\mathrm{N}_{2}$ & bal. & bal. & bal. \\
\hline$\lambda$ & 1.41 & 0.81 & 1.20 \\
\hline Duration, $\mathrm{s}$ & $30-120$ & $5-15$ & 5 \\
\hline $\begin{array}{l}\mathrm{Hydrothermal} \text { ageing was performed parallel for } 12 \text { samples using } \\
10 \% \text { water in air at } 700-800{ }^{\circ} \mathrm{C} \text { for } 20 \mathrm{~h}\end{array}$ \\
\hline
\end{tabular}

The surface area and pore size distribution were detected by the standard BET (Brunauer-Emmet-Teller) method with nitrogen adsorption-desorption isotherms (Sorptomatic 1990). The $\mathrm{NH}_{3}$ adsorption-desorption was detected by the activity test reactor by adsorbing $\mathrm{NH}_{3}$ at $200^{\circ} \mathrm{C}$ by a step exchange experiment $\left(0 \rightarrow 500 \mathrm{ppm} \mathrm{NH}_{3}\right.$ in nitrogen, $\left.42.000 \mathrm{~h}^{-1}\right)$ and then the desorption of $\mathrm{NH}_{3}$ was detected in the presence of $10 \%$ oxygen in nitrogen (Temperature programmed Oxidation (TPO) experiment) by a ramp of $20{ }^{\circ} \mathrm{C} / \mathrm{min}$ up to $600{ }^{\circ} \mathrm{C}$ [11].

\subsection{Engine-bench experiments for catalyst development}

The engine experiments were conducted with a $1.2 \mathrm{~L}$ turbocharged diesel engine equipped with DOC+DPF system before LNT+SCR [12]. The experimental conditions were simplified for catalyst development purposes and these experiments were done using all-in-line system together with the assistance of engine management system to make periodic enrichments to purge LNT. After system development, the lean period was $150 \mathrm{~s}$ and rich period $15 \mathrm{~s}$ with $\lambda$ of 0.95 in the selected conditions. The emissions after engine, DOC+DPF, LNT and SCR were measured by the sample gas collected to the FTIR analyzer (Gasmet) calibrated for exhaust gas components. $\lambda$ values and temperatures were detected also in these positions.

\section{Results and discussions}

\subsection{Development of Lean NOx Traps}

$\mathrm{NO}_{x}$ adsorbent containing LNTs have been used also commercially since 1990 's, first for lean gasoline and later for diesel passenger car applications. Platinum and rhodium are the most active platinum group metals (PGMs) to form $\mathrm{NO}_{2}$ in lean phases and reduce $\mathrm{NO}_{x}$ in rich periods. The development was thus focused on PtRh catalyst compositions with higher loadings like above $80 \mathrm{~g} / \mathrm{cft}$. Ceria containing oxygen storage compounds (OSC) were used as promoters in the coating to enhance LNT performance.

The rich periods are decreasing fuel economy and their duration should be minimized together with the target $\mathrm{NO}_{\mathrm{x}}$ conversion. The rich periods cause higher $\mathrm{CO}, \mathrm{HC}, \mathrm{PM}$ and ammonia peak concentrations which magnitude can be are controlled by adjusting the lean-rich timings. Usually nitrates in LNT are not completely reduced during rich peaks to avoid the flow-through of reductants $(\mathrm{CO} / \mathrm{HC})$ and $\mathrm{NH}_{3}$ emissions but a part of nitrates remains on the catalyst surface. The presence of a SCR catalyst after LNT enables to utilize more complete reduction steps because ammonia will be cut down by SCR.

The development of LNTs was based on periodic lean-rich excursions (L60s/R5s, L = Lean, $\mathrm{R}=\mathrm{Rich}$ ) with hydrothermally aged $\left(700{ }^{\circ} \mathrm{C} / 20 \mathrm{~h}\right)$ samples. Pt as a main catalytic metal together with $\mathrm{Rh}$ was needed as well as $\mathrm{NO}_{\mathrm{x}}$ adsorbents, oxygen storage compounds to have an active LNT (Fig. 2). The co-operation of Pt, Rh, OSC and $\mathrm{NO}_{\mathrm{x}}$ adsorbent were optimized tailoring the relative concentrations, raw materials and preparation methods. The Pt-only LNT showed also quite high $\mathrm{NO}_{\mathrm{x}}$ efficiency, being the most active at high temperatures. Even if $\mathrm{Rh}$ had minor effect in these laboratory simulations, it has a role in transient enrichment peaks to maintain a high efficiency with a low amount of unwanted side products. It was seen that a high Pt loading resulted in a slight improvement in light-off region below $200^{\circ} \mathrm{C}$, which is important for light-duty driving conditions (9). In addition, the Pt reserve has also a role to improve the durability of LNT in long-term use.

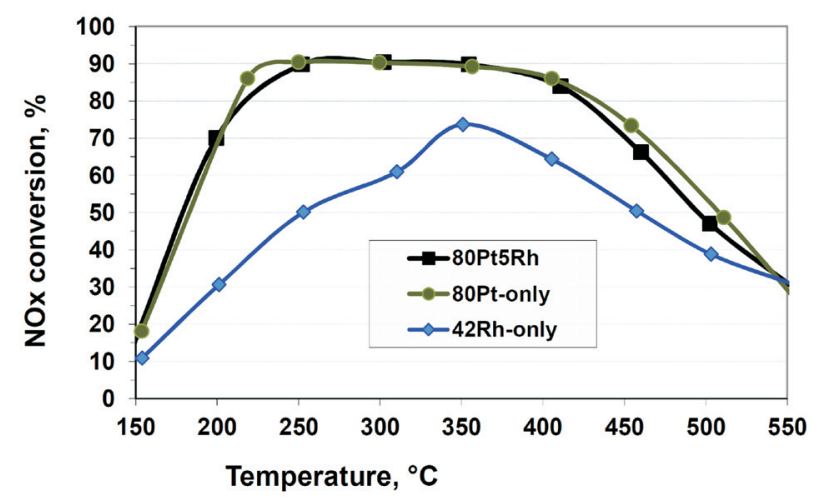

Fig. 2. $\mathrm{NO}_{\mathrm{x}}$ efficiency by $\mathrm{Pt}$ and $\mathrm{Rh}$ loadings (g/cft in the legend) on $\mathrm{Ba}$ and rare earth containing LNT by a laboratory simulations (samples hydrothermally aged at $700{ }^{\circ} \mathrm{C} / 20 \mathrm{~h}, \mathrm{SV} 30.000 \mathrm{~h}^{-1}$, timing L60s/R5s)

In our simulations, the oxygen storage compounds (Ceria) were found to promote the total $\mathrm{NO}_{\mathrm{x}}$ conversion to nitrogen and $\mathrm{NH}_{3}$. Therefore, the oxygen storage capacity (OSC) has not a buffering effect like detected in a passive TWC + SCR system in near to stoichiometric mean conditions with lean gasoline application [13]. It is important to use thermally stable, sulfur-resistance oxygen storage compounds in LNTs. The ceria promotion for LNT reactions has been also proposed for Pt catalysts earlier [14].

\subsection{Development of SCR catalysts for LNT + SCR concept}

Various copper, iron and vanadium based SCR catalysts were screened by $\mathrm{NH}_{3}-\mathrm{SCR}, \mathrm{LNT}+\mathrm{SCR}$ and durability stud- 
ies (surface area, ammonia adsorption capacity and activity with $\mathrm{NO}$ and $\mathrm{NO}+\mathrm{NO}_{2}$ ) in the preliminary studies [9]. Because LNT + SCR systems are mainly applied for light-duty applications which test and driving conditions are focused on low temperatures $\left(100-250^{\circ} \mathrm{C}\right)$, the catalyst evaluations were also zoomed in that region. In DOC + DPF + LNT systems, the peak temperatures are above $700{ }^{\circ} \mathrm{C}$ on DPF and LNT. The SCR catalyst located after LNT should be active in NO only SCR reactions (standard SCR), because $\mathrm{NO}_{2}$ formed on DOC or catalyzed DPF have been consumed in LNT. Copper based SCR catalyst showed a wide operation window without $\mathrm{NO}_{2}$ and also a good low temperature functionality (Fig. 3). The Fe-SCR catalyst was more dependent on the promotion of $\mathrm{NO}_{2}$ at low temperatures. Therefore, the iron catalyst had a limited low temperature SCR activity in the absence of $\mathrm{NO}_{2}$. However, $\mathrm{NO}_{2}$ promotion was clear both on $\mathrm{Cu}$ and $\mathrm{Fe} \mathrm{SCR}$ catalysts aged at $800^{\circ} \mathrm{C}$. It can be assumed that $\mathrm{NO}_{2}$ promotion has a higher effect on aged than on fresh catalyst, which has more active catalyst surface available. $\mathrm{Cu}$ and $\mathrm{Fe}$ catalyst showed stable SCR activity up to ageing temperatures of $800^{\circ} \mathrm{C}$. V-SCR had a limited durability and it was similar to Fe-SCR catalysts also highly dependent on $\mathrm{NO}_{2}$ promotion at low temperatures [9]. As a summary, copper and iron based SCR catalysts were thus most durable for the target application. Therefore, the Cu-SCR1 catalyst was applied for full-scale LNT + SCR studies with diesel engine due to the observed properties at low temperatures and for SCR after LNT.

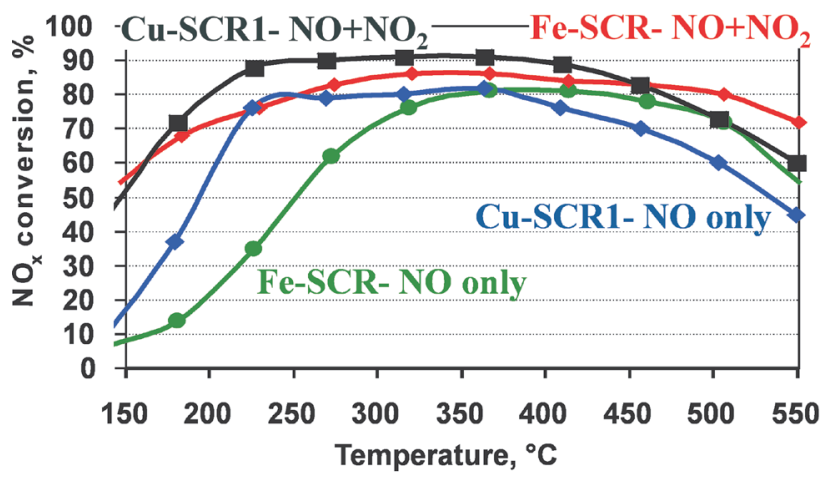

Fig. 3. $\mathrm{NO}_{\mathrm{x}}$ efficiency on hydrothermal aged $\left(800{ }^{\circ} \mathrm{C}\right.$ for $\left.20 \mathrm{~h}\right)$ copper and iron SCR catalysts in standard SCR reaction (no $\mathrm{NO}_{2}, \mathrm{SV} 50.000 \mathrm{~h}^{-1}$, $\left.\mathrm{NH}_{3} / \mathrm{NO}=1\right)$

Many SCR catalysts may lose $\mathrm{NH}_{3}$ adsorption capacity in the ageing conditions in the SCR position after LNT and DPF. The $\mathrm{Cu}-\mathrm{SCR}$ catalysts showed a stable $\mathrm{NH}_{3}$ adsorption capacity at $200{ }^{\circ} \mathrm{C}$ up to the ageing temperatures at $800{ }^{\circ} \mathrm{C}$ (Fig. 4). A V-SCR catalyst had lower adsorption ability at $200{ }^{\circ} \mathrm{C}$ and it still lost the adsorption capacity after ageing at 700 and $800^{\circ} \mathrm{C}$. PtRh/LNT had also a low ability for ammonia adsorption but that was only $5 \%$ of that of $\mathrm{Cu}-\mathrm{SCR} 1$ as fresh.

After adsorption steps, SCR catalysts were treated in temperature programmed oxidation (TPO) in lean gas mixture (Fig. 5). The ammonia desorption as a function of temperature at $200-600^{\circ} \mathrm{C}$ is a fingerprint about the ammonia adsorption strength on catalyst surface. A part of ammonia was oxidized to $\mathrm{NO}$ and $\mathrm{N}_{2} \mathrm{O}$ (not shown here), which relative amounts varied by the catalyst type and ageing state. The $\mathrm{Cu}$ SCR catalysts with a high adsorption capacity and strength after ageing at $700-800^{\circ} \mathrm{C}$ were thus the most potential for $\mathrm{LNT}+\mathrm{SCR}$ applications, where $\mathrm{NH}_{3}$ formed in rich periods will be adsorbed downstream on the SCR unit and further utilized in SCR reactions in lean periods.

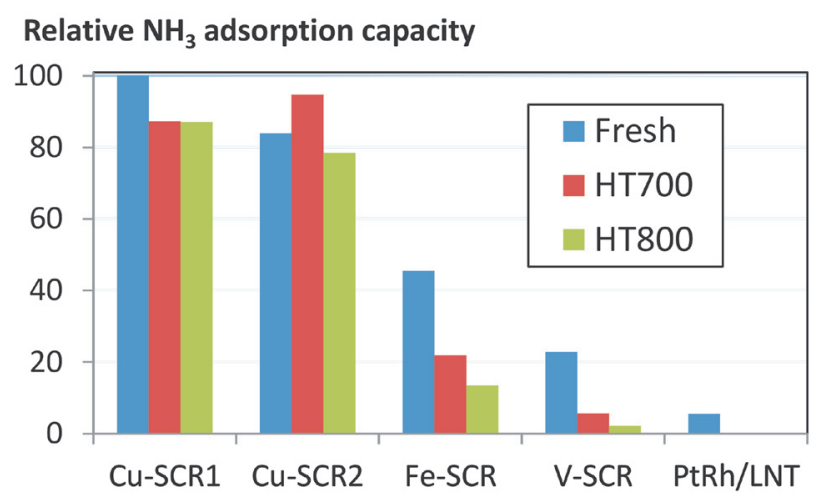

Fig. 4. Relative, coating weight based $\mathrm{NH}_{3}$ adsorption capacity of studied SCR catalysts and $\mathrm{PtRh} / \mathrm{LNT}$ at $200{ }^{\circ} \mathrm{C}$ as fresh and hydrothermally aged

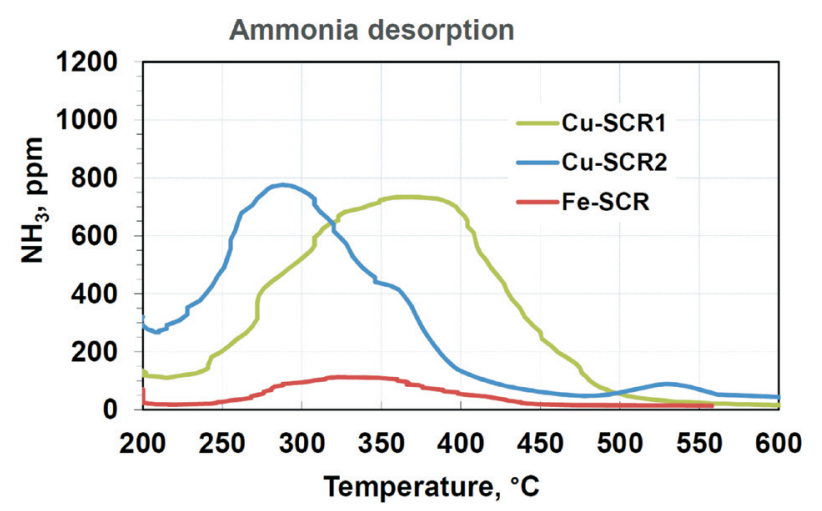

Fig. 5. Ammonia desorption from HT800 aged SCR catalysts in TPO experiments between $200-600{ }^{\circ} \mathrm{C}(10 \%$ oxygen in nitrogen). Adsorption capacity totally filled by $\mathrm{NH}_{3}$ at $200^{\circ} \mathrm{C}$ before that TPO

\subsection{Effect of reaction conditions on LNT+SCR performance \\ Duration of lean phase}

After optimizing the PtRh/LNT and SCR catalyst composition [9, 12], the selected, most active catalysts were applied for LNT + SCR simulation with synthetic feed gases. The lean-rich timing has the direct effect on the $\mathrm{NO}_{\mathrm{x}}$ storage and reduction abilities. In real-life, the lean-rich timing correlates directly to fuel economy: the shorter is the rich period and the longer is the lean period, the better is the fuel economy. Enrichments increase always the fuel consumption with diesel engines optimized to economic lean combustion. Both the duration and frequency of rich periods are meaningful. $\mathrm{NO}_{\mathrm{x}}$ adsorption capacity depends on the duration of lean period, if the surface is mainly emptied of adsorbed $\mathrm{NO}_{\mathrm{x}}$ by the efficient reduction. The long, two minutes lean period resulted in lower $\mathrm{NO}_{\mathrm{x}}$ activity in the laboratory simulations particularly at high temperatures, where the $\mathrm{NO}_{\mathrm{x}}$ storage 
capacity became limiting and the real residence time is shorter due to the temperature effect (Fig. 6). The relative $\mathrm{NH}_{3}$ formation was lower with $120 \mathrm{~s}$ lean experiments. Too short $30 \mathrm{~s}$ lean period did not anymore improve the mean $\mathrm{NO}_{x}$ conversion compared to the standard $60 \mathrm{~s}$ lean one but that short lean period between efficient enrichments $(5 \mathrm{~s}$ with $\lambda=0.86$ ) had a slight negative effect.
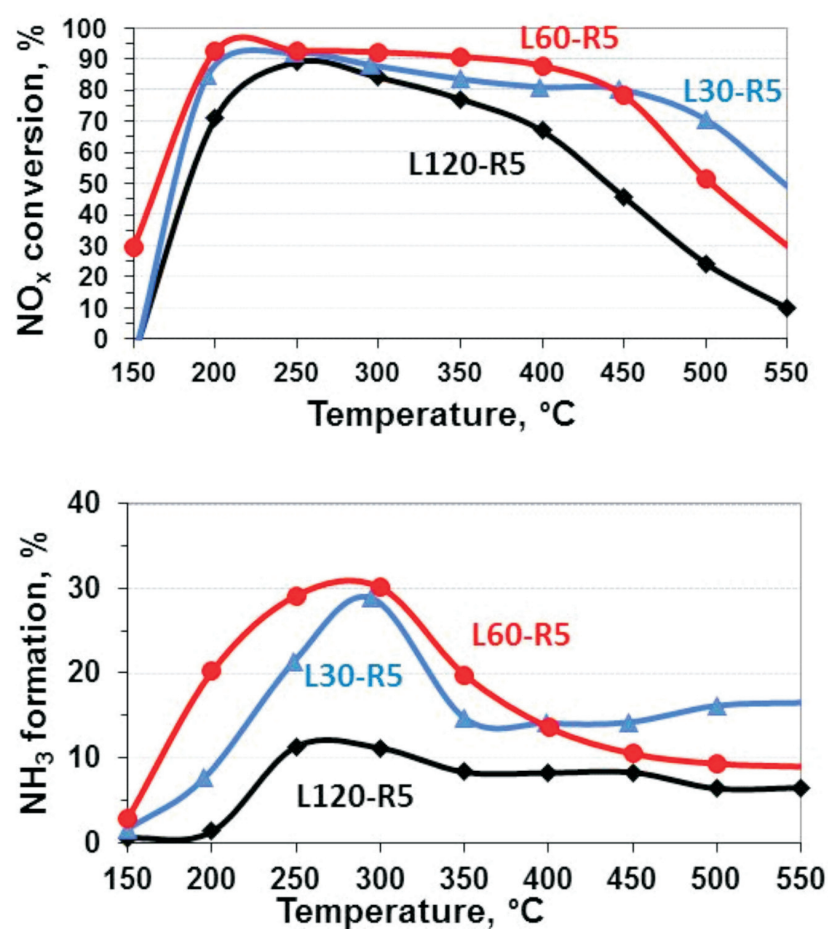

Fig. 6. The effect of the lean phase duration (30-120 s, rich $5 \mathrm{~s}$ ) on $\mathrm{NO}_{\mathrm{x}}$ efficiency and $\mathrm{NH}_{3}$ formation with $80 \mathrm{Pt} 5 \mathrm{Rh} / \mathrm{LNT} 1+\mathrm{Cu}-\mathrm{SCR} 1$ $\left(30.000+60.000 \mathrm{~h}^{-1}\right)$

\section{$L N T+S C R$ simulations}

The $\mathrm{NO}_{\mathrm{x}}$ efficiency was higher with the assistance of SCR than with LNT only with the same total space velocity at low temperatures. At high temperatures, LNT only were detected to reach higher $\mathrm{NO}_{x}$ efficiency with the same total catalyst volume but the presence of SCR unit prevents the ammonia emissions. The $\mathrm{NO}_{\mathrm{x}}$ adsorption (storage) capacity per coating amount (grams) on $\mathrm{NO}_{\mathrm{x}}$ adsorbents decreases a function of temperature, which limits the high temperature $\mathrm{NO}_{\mathrm{x}}$ conversion. This is also a reason together with the fuel economy, why LNTs are not that competitive with urea-SCR catalysts in heavy-duty applications (highway trucks) which have exhaust gas temperatures of about $300-550{ }^{\circ} \mathrm{C}$ in the driving conditions and test cycles.

$\mathrm{NO}_{x}$ conversion and the emissions of $\mathrm{NH}_{3}$ and $\mathrm{N}_{2} \mathrm{O}$ were detected in the comparison between LNT only and the LNT with a varying SCR unit (Fig. 7) LNT only resulted in high mean $\mathrm{NH}_{3}$ formation due to very rich peaks $(\lambda=0.82$ for $5 \mathrm{~s}$ ) in simulation. In these conditions, it was possible to utilize SCR functionality in reaction studies downstream LNT. Both copper and iron based SCR catalysts were able to cut ammonia down and increased particularly the low temperature activity, which is important for passenger car applications. The LNT volume was the same in every experiment $\left(30.000 \mathrm{~h}^{-1}\right)$ and SCR was an additional volume after that fixed LNT. When that SCR unit was added after the LNT only, the $\mathrm{NO}_{\mathrm{x}}$ conversion was higher and $\mathrm{NH}_{3}$ slip still lower but that design meant $50 \%$ larger total volume. In this simulation, $\mathrm{N}_{2} \mathrm{O}$ formation was related solely to $\mathrm{HC}-\mathrm{SCR}$ (propene as HC) at low temperatures in lean side, almost no side reaction to $\mathrm{N}_{2} \mathrm{O}$ was detected during enrichment peaks and the type of SCR catalyst had negligible effect on $\mathrm{N}_{2} \mathrm{O}$ formation. However, in real exhaust gas HCs are less active for HC-SCR than one of most reactive $\mathrm{HC}$, propene used in this simulation. Relative $\mathrm{HC}-\mathrm{SCR}$ effect on $\mathrm{N}_{2} \mathrm{O}$ formation may be about $10-30 \%$ (the fraction of $\mathrm{HC}-\mathrm{SCR}$ reactive $\mathrm{HCs}$ in diesel exhaust) of these observed formation rates in real diesel exhaust gases. The same HC-SCR reaction will happen in the real system first on Pt-based DOC, located before LNT. Therefore, the presence of LNT in diesel system does not increase the potential for $\mathrm{N}_{2} \mathrm{O}$ formation.
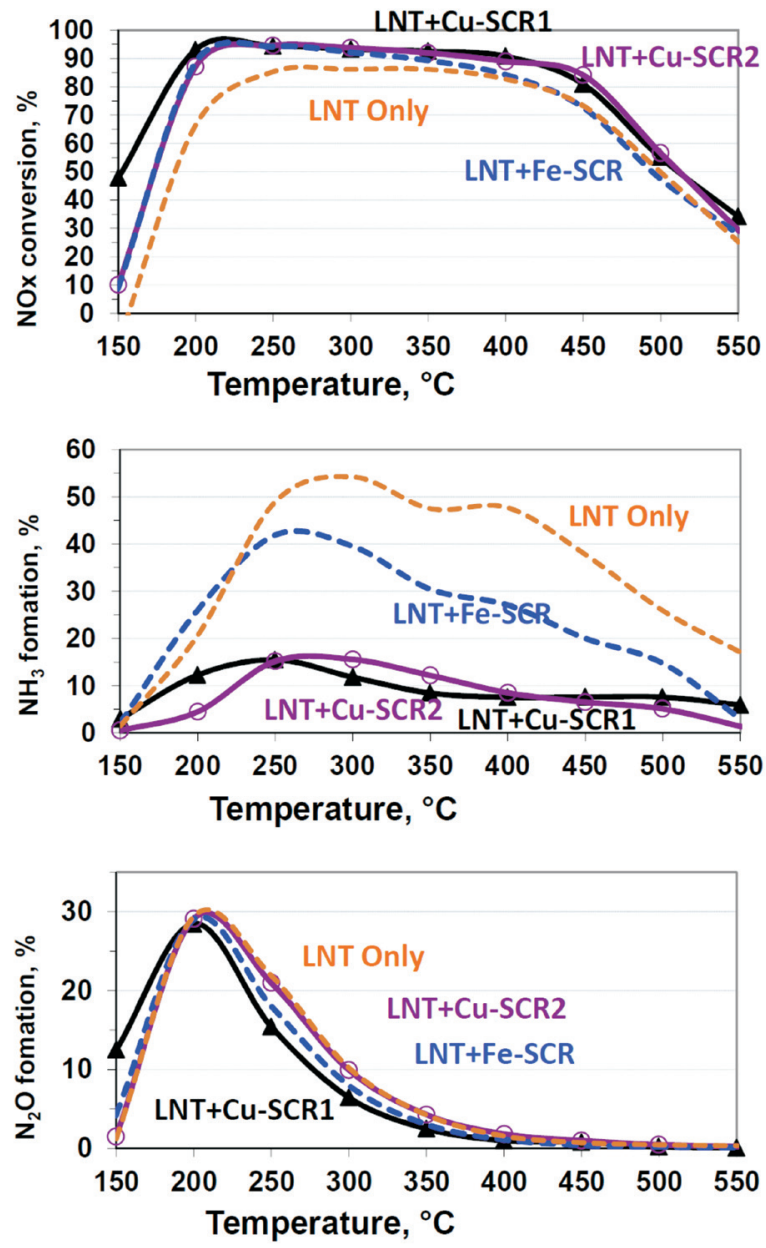

Fig. 7. The effect of SCR catalyst type on the $\mathrm{NO}_{\mathrm{x}}$ efficiency together with $\mathrm{NH}_{3}$ and $\mathrm{N}_{2} \mathrm{O}$ formation in L60-R5 laboratory simulation (LNT $+\mathrm{SCR}=75+75^{2} \mathrm{~mm}=30.000+30.000 \mathrm{~h}^{-1}, 80 \mathrm{~g} / \mathrm{cft} \mathrm{Pt}$ and $5 \mathrm{~g} / \mathrm{cft} \mathrm{Rh}$ on LNT, LNT only $=75 \mathrm{~mm}=30.000 \mathrm{~h}^{-1}$ )

The Cu-SCR catalysts were able to promote the LNT performance with suppressed $\mathrm{NH}_{3}$ formation particularly at low temperatures. In this lean-rich condition, the presence 
of the SCR unit resulted in lower $\mathrm{NH}_{3}$ formation compared to large LNT only. Cu-SCR catalysts are able to promote LNT also with a smaller volume $\left(60.000 \mathrm{~h}^{-1}\right)$, opposite to Fe-SCR catalyst [9]. The $\mathrm{NH}_{3}$ emissions were quite high (max. 40-50\%) with LNT only, which experimental conditions made the effect of SCR quite dominating. $\mathrm{NH}_{3}$ formation- $\%$ and $\mathrm{N}_{2} \mathrm{O}$ formation- $\%$ were calculated by the inlet NOx concentration. All detected N-O and N-H compounds originated from feed $\mathrm{NO}_{x}$.

The promotion of Fe-SCR catalyst on $\mathrm{NO}_{x}$ conversion was similar like with $\mathrm{Cu}-\mathrm{SCR}$ catalyst. The total $\mathrm{NO}_{\mathrm{x}}$ efficiency was slightly lower than with the $\mathrm{Cu}$ catalyst at high temperatures. That large Fe-SCR unit $\left(30.000 \mathrm{~h}^{-1}\right)$ was able to promote also low temperature SCR but our other studies showed that SCR below $300{ }^{\circ} \mathrm{C}$ was more limited with Fe-SCR than with $\mathrm{Cu}-\mathrm{SCR}$ when SV was $60.000 \mathrm{~h}^{-1}$ over SCR unit [9]. The use of $\mathrm{Fe}-\mathrm{SCR}$ resulted in higher $\mathrm{NH}_{3}$ emissions (max. $42 \%$ ) than the use of Cu-SCR (max. 14\%). This difference is a key property to use $\mathrm{Cu}-\mathrm{SCR}$ in the further full-scale studies.

The LNT + SCR design was optimized in many other experiments by varying the volume of catalyst units and lean-rich timings. The optimal design was targeting the maximal $\mathrm{NO}_{\mathrm{x}}$ efficiency and minimal $\mathrm{NH}_{3}$ slip after the complete system. Any additional volume of units should be avoided to keep pressure drop and costs of the units low.

3.4. Shifting SCR unit to lean during the LNT regeneration-air addition

In LNT + SCR system the ammonia concentration can be adjusted to a higher level after LNT than in LNT-only systems, because formed ammonia will react on the SCR unit. This combination results in a higher total $\mathrm{NO}_{\mathrm{x}}$ efficiency but traces of $\mathrm{NH}_{3}$ may be left even after the SCR unit, because the conventional SCR catalysts are not good in long rich or stoichiometric periods. It is difficult to store all formed $\mathrm{NH}_{3}$ on the SCR unit in rich and to have then the reaction with stored $\mathrm{NH}_{3}$ and feed $\mathrm{NO}$ in lean. After the change from rich to lean the $\mathrm{NH}_{3} / \mathrm{NO}_{\mathrm{x}}$ (gaseous+adsorbed) ratio is very high, which results in $\mathrm{NH}_{3}$ slip. In conventional $\mathrm{NH}_{3}-\mathrm{SCR}$ systems, the $\mathrm{NH}_{3} / \mathrm{NO}_{\mathrm{x}}$ ratio is fixed near to the value of 1 with the known (model-based) $\mathrm{NH}_{3}$ storage on the SCR catalyst surface. In LNT + SCR system, that $\mathrm{NH}_{3} / \mathrm{NO}_{\mathrm{x}}$ ratio varies in the wide range. The continuous lean SCR condition promoted SCR and thus total $\mathrm{NO}_{x}$ efficiency to $\mathrm{N}_{2}$ with lower $\mathrm{NH}_{3}$ emissions. Oxygen and $\mathrm{NO}_{2}$ promote the SCR reactions on conventional SCR catalysts, which promotion is missing in rich.

Therefore, an approach is to keep the SCR unit continuously in lean side, also during LNT regenerations. In by-pass LNT + SCR systems [12] the SCR unit will be also always in lean side, which functionality we also simulated in this experimental procedure. In our laboratory simulations, $\lambda$ was 1.2 on the SCR unit by the assistance of an additional air injection for the SCR unit, when $\lambda$ was at the same time 0.81 on LNT during regeneration periods (Fig. 8).

The lean condition had a minor effect on detected $\mathrm{NO}_{\mathrm{x}}$ conversion, but the selectivity to desired $\mathrm{N}_{2}$ instead of ammonia was higher with this air assistance. The use of air addition made the volume of the SCR unit more critical, opposite to the results without air addition. The increase of SCR catalyst volume $\left(111.000 \rightarrow 30.000 \mathrm{~h}^{-1}\right)$ dropped $\mathrm{NH}_{3}$ formation degree from 30 to $5 \%$ in L60-R5 conditions [9].
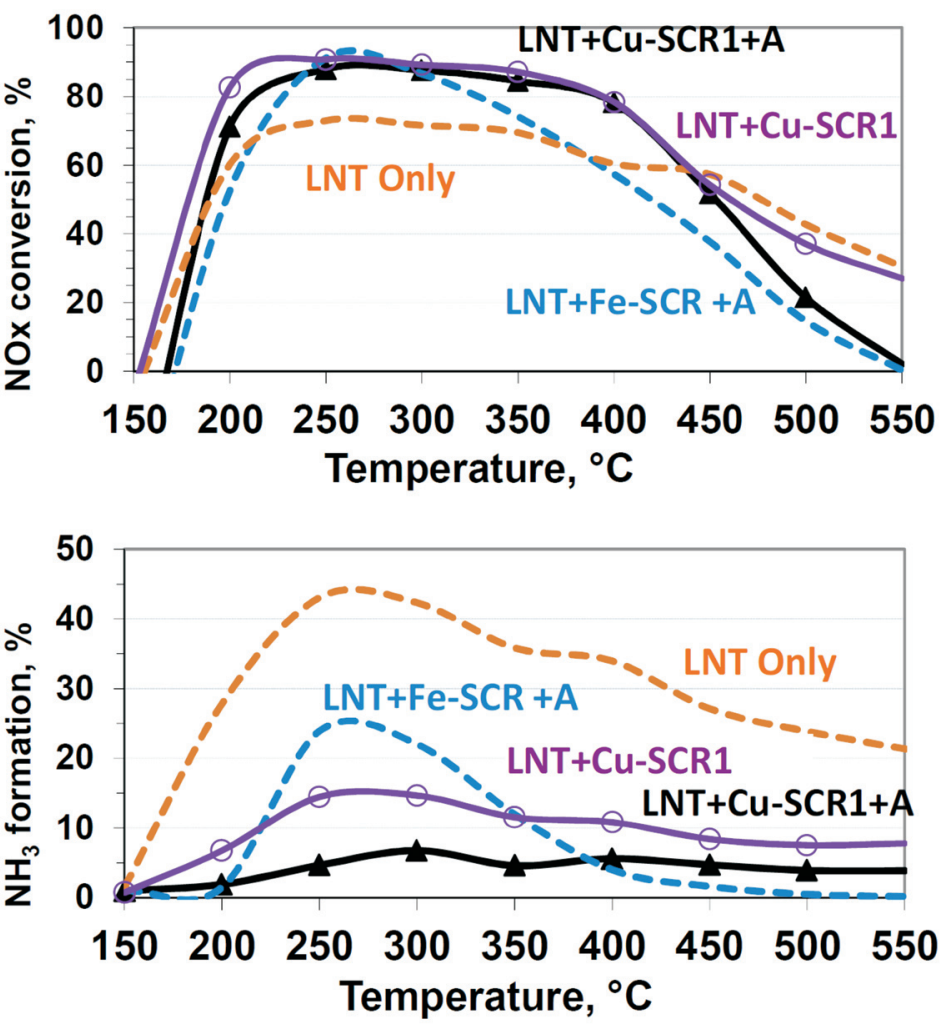

Fig. 8. The effect of air addition before the SCR unit on $\mathrm{NO}_{x}$ efficiency and $\mathrm{NH}_{3}$ formation with fresh LNT and SCR catalyst combinations in L60-R5 conditions $\left(37 \mathrm{~mm}+75 \mathrm{~mm}=60.000 \mathrm{~h}^{-1}+30.000 \mathrm{~h}^{-1}\right)$

\subsection{Engine experiments for catalyst development}

LNT and SCR catalysts developed by the small-scale samples were further prepared as full-scale and examined as combinations with the $1.2 \mathrm{~L}$ engine in lean-rich operation. Higher $\mathrm{NH}_{3}$ emissions were detected after LNT due to the long rich period ( $15 \mathrm{~s}$ ), even if $\lambda$ was not that low as in the rich mixture of laboratory experiments. The combination of LNT and SCR was installed in series by flow direction without any air addition, which was too complicated to add in this experimental set-up. However, ammonia adsorbed in rich period will react later in lean period also in this set-up.

The assistance of SCR unit for LNT performance was well seen in these experiments (Fig. 9). The Cu-SCR1 catalyst promoted $\mathrm{NH}_{3}-\mathrm{SCR}$ reaction, which increased the total $\mathrm{NO}_{x}$ efficiency and removed $\mathrm{NH}_{3}$, formed on LNT, out from exhaust outlet. In the selected two engine points the mean temperature was after SCR about 180 and $270{ }^{\circ} \mathrm{C}$ in that lean-rich operation. $\mathrm{NO}_{\mathrm{x}}$ conversion increased from 43 to 
$95 \%$ in the point of $180{ }^{\circ} \mathrm{C}$ and from 80 to $96 \%$ in the point of $270{ }^{\circ} \mathrm{C}$. In these experimental conditions, the SCR unit was necessary to reach the target $\mathrm{NO}_{\mathrm{x}}$ conversion without ammonia emissions. These simulation results were used as a base for the LNT and SCR catalyst samples used in the partners' engine and vehicle studies in this joint Powerful EU program.

$$
\begin{aligned}
& \mathrm{C}_{3} \mathrm{H}_{6}+2 \mathrm{NO}+4.5 \mathrm{O}_{2} \rightarrow 3 \mathrm{CO}_{2}+\mathrm{N}_{2}+3 \mathrm{H}_{2} \mathrm{O} \\
& \mathrm{C}_{3} \mathrm{H}_{6}+2 \mathrm{NO}+5 \mathrm{O}_{2} \rightarrow 3 \mathrm{CO}_{2}+\mathrm{N}_{2} \mathrm{O}+3 \mathrm{H}_{2} \mathrm{O} \\
& \mathrm{NO}+\mathrm{CO} \rightarrow \mathrm{CO}_{2}+0.5 \mathrm{~N}_{2} \\
& 2 \mathrm{NO}+2 \mathrm{H}_{2} \rightarrow \mathrm{N}_{2}+2 \mathrm{H}_{2} \mathrm{O}
\end{aligned}
$$

(4) $\mathrm{C}_{3} \mathrm{H}_{6}-$ $\mathrm{SCR}$ in lean (5) $\mathrm{N}_{2} \mathrm{O}$ formation in lean (6) NO reduction by $\mathrm{CO}$ in rich

(7) NO reduction by $\mathrm{H}_{2}$ in rich
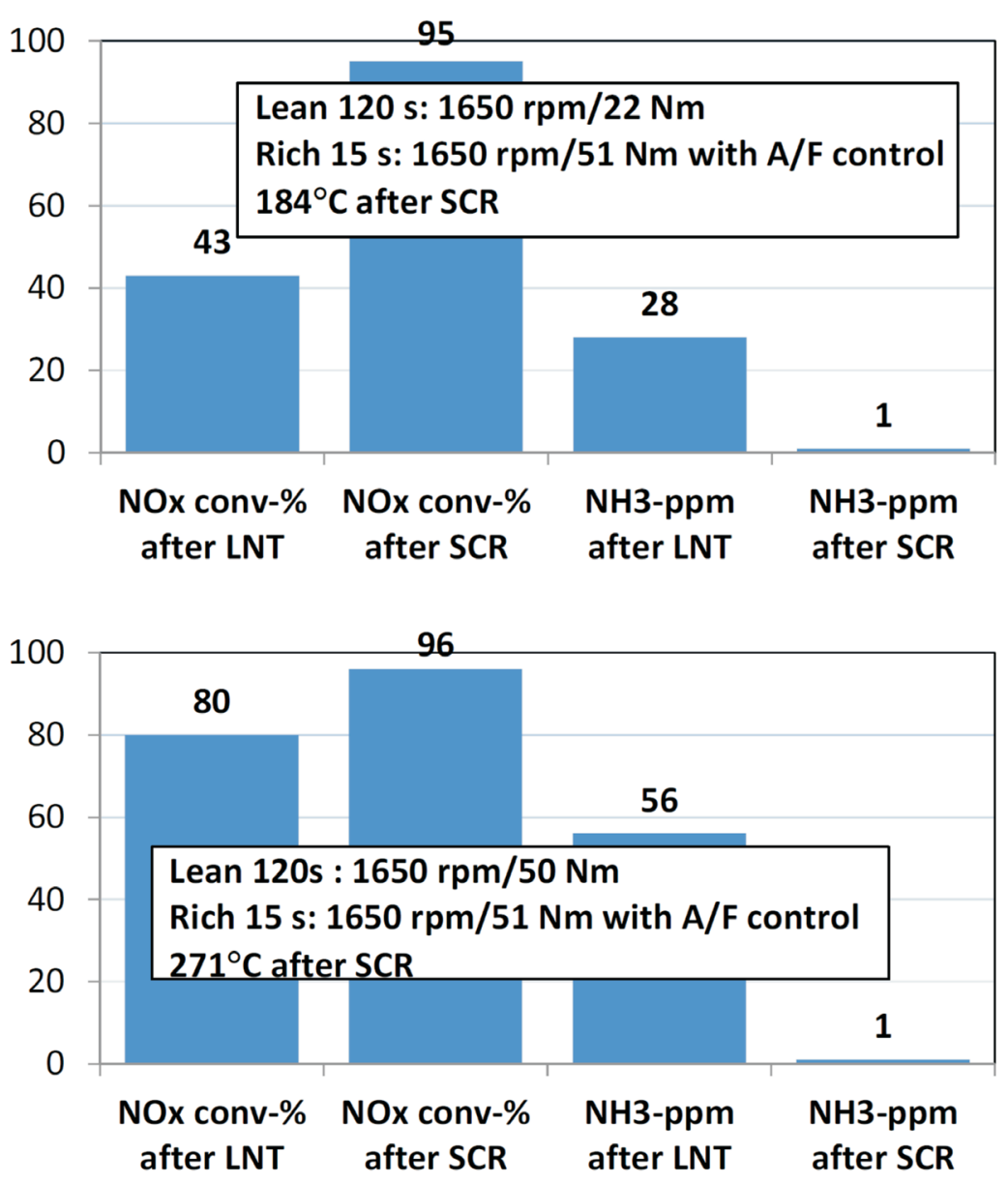

Fig. 9. The effect of $\mathrm{Cu}-\mathrm{SCR} 1$ on the $\mathrm{NO}_{x}$ conversion and $\mathrm{NH}_{3}$ formation with $80 \mathrm{Pt} 5 \mathrm{Rh} / \mathrm{LNT}$ in two engine points with a $1.2 \mathrm{~L}$ diesel engine (LNT 1.4 L, SCR 1.9L). The shown values are mean values by the last 5 cycles of 8 repeated cycles in L120-R15 cycling in both engine point

\subsection{Reaction mechanism in LNT + SCR system}

The reaction mechanism in this combinatory system can be described by the known LNT and SCR reaction paths. The LNT operation can be calibrated to form more ammonia than with known LNT only systems. The formed $\mathrm{NH}_{3}$ will react on the SCR unit. $\mathrm{NH}_{3}$ is formed with the $\lambda$ values below 1 in known 3-way catalyst reactions. The main $\mathrm{NO}_{\mathrm{x}}$ reactions on LNT can be presented as follows $[9,10,15,16]$ :

$$
\begin{aligned}
& \mathrm{NO}+0.5 \mathrm{O}_{2} \leftrightarrow \mathrm{NO}_{2} \\
& \mathrm{NO}_{2}+0.5 \mathrm{O}_{2}+\mathrm{BaO} \leftrightarrow \mathrm{Ba}\left(\mathrm{NO}_{3}\right)_{2}
\end{aligned}
$$

(1) $\mathrm{NO}_{2}$ formation and decomposition in lean (2) $\mathrm{NO}_{2}$ adsorption in lean and desorption in rich

$\mathrm{NO}+2.5 \mathrm{H}_{2} \rightarrow \mathrm{H}_{2} \mathrm{O}+\mathrm{NH}_{3} \quad$ (3) $\mathrm{NH}_{3}$ formation in rich
The adsorbed $\mathrm{NO}_{\mathrm{x}}$ (nitrate, nitrite) on $\mathrm{BaO}$ will be desorbed and decomposed to $\mathrm{NO}$ in reducing conditions, which equilibrium is controlled by thermodynamics and kinetics. $\mathrm{NO}$ is reduced by $\mathrm{CO}$ or $\mathrm{H}_{2}$ formed from partial $\mathrm{HC}$ oxidation, water gas shift and gas reforming reactions. The gaseous $\mathrm{NO}_{2}$ concentrations in the LNT reactor outlet are very low in lean-rich conditions, due to adsorption (in lean) and reducing (in rich) conditions. Propene represents $\mathrm{HCs}$ in our experiments and those equations and it is also a source for the final reductants $\left(\mathrm{H}_{2}\right.$ and $\left.\mathrm{CO}\right)$ of $\mathrm{NO}_{x}$. $\mathrm{C}_{3} \mathrm{H}_{6}-\mathrm{SCR}$ on $\mathrm{PtRh} / \mathrm{LNT}$ results also in a low $\mathrm{NO}_{\mathrm{x}}$ conversion around at $200-300{ }^{\circ} \mathrm{C}$ (eq. 4). $\mathrm{N}_{2} \mathrm{O}$ is a by-product in this reaction sequence (eq. 5). The oxygen storage capacity (OSC) has also a role in lean-rich excursions and 3-way catalyst performance but those reactions are not included in this general $\mathrm{NO}_{\mathrm{x}}$ reaction path description. The detailed surface reaction mechanisms are much more complex [17] but the above reactions describe the main paths related to reaction rates of observed reactants and products in reactor inlet and outlet.

$\mathrm{NH}_{3}$ formed in LNT will adsorb and react on SCR catalyst mainly in rich phase. Standard SCR is the main $\mathrm{NO}_{\mathrm{x}}$ reduction path in that after LNT position. A part of $\mathrm{NH}_{3}$ may be oxidized also back to $\mathrm{NO}$, particularly at higher temperatures. $\mathrm{NH}_{3}$ is presented below to react with gaseous NO as an adsorbed intermediate but it has been also presented mechanisms where both reactants are adsorbed or $\mathrm{NH}_{3}$ is in gas phase. However, $\mathrm{NH}_{3}$ adsorption step has a key role in this LNT + SCR system to move adsorbed $\mathrm{NH}_{3}$ to be utilized in the following lean period. Therefore, ammonia adsorption was included in this simplified reaction set. The $\mathrm{NO}_{\mathrm{x}}$ main reactions on SCR unit can be presented as follows:

$$
\begin{array}{lr}
\mathrm{NH}_{3}+* \leftrightarrow \mathrm{NH}_{3}^{*} & \begin{array}{r}
\text { (8) } \mathrm{NH}_{3} \text { adsorption on } \\
\text { surface site (*) in rich }
\end{array} \\
4 \mathrm{NH}_{3}^{*}+4 \mathrm{NO}+\mathrm{O}_{2} \rightarrow 4 \mathrm{~N}_{2}+6 \mathrm{H}_{2} \mathrm{O}+4 * & \text { (9) SCR with } \\
& \text { NO only in lean } \\
\mathrm{NH}_{3}^{*}+\mathrm{NO} \rightarrow \mathrm{N}_{2}+1.5 \mathrm{H}_{2} \mathrm{O}+* & \text { (10) SCR in rich } \\
4 \mathrm{NH}_{3}^{*}+3 \mathrm{O}_{2} \rightarrow 2 \mathrm{~N}_{2}+6 \mathrm{H}_{2} \mathrm{O}+4 * & \text { (11) } \mathrm{NH}_{3}
\end{array}
$$

decomposition in lean 
$4 \mathrm{NH}_{3}^{*}+5 \mathrm{O}_{2} \rightarrow 4 \mathrm{NO}+6 \mathrm{H}_{2} \mathrm{O}+4 *$

(12) $\mathrm{NH}_{3}$ oxidation to $\mathrm{NO}$ in lean

In more detailed surface mechanism, many other surface intermediates and competing reaction paths exist. In fact, SCR reaction (on $\mathrm{Cu}$ ) and $\mathrm{NH}_{3}$ adsorption (on support) proceed on separate catalyst sites.

\section{Summary}

The LNT and SCR catalysts were developed and optimized for LNT + SCR applications. Pt-Rh catalysts with optimized support, PtRh loadings, $\mathrm{NO}_{\mathrm{x}}$ adsorbents and oxygen storage compounds resulted in an efficient LNT composition. The $\mathrm{Cu}-\mathrm{SCR}$ catalysts showed a good durability up to $800^{\circ} \mathrm{C}$ and a wide operation window without $\mathrm{NO}_{2}$ assistance. FeSCR and $\mathrm{V}-\mathrm{SCR}$ catalysts had lower $\mathrm{NH}_{3}$ adsorption capacity and they were dependent on $\mathrm{NO}_{2}$, which promotion is not possible to apply in the SCR position after LNT and DPF. The SCR unit after LNT was able to increase total $\mathrm{NO}_{\mathrm{x}}$ efficiency and remove $\mathrm{NH}_{3}$ emissions during powerful enrichments.

The design of LNT + SCR was optimized for the developed concept by catalyst volumes (SV) and lean-rich timing. The concept variation for real diesel applications with DPF units was analyzed. The main application for this kind system will be light-duty vehicles, where the use of LNTs is known and the low temperature $\mathrm{NO}_{\mathrm{x}}$ removal is the main target. The use a SCR unit after LNT enabled to reach higher NO efficiencies by the use of heavier enrichments without $\mathrm{NH}_{3}$ emissions, because $\mathrm{NH}_{3}$ is consumed in SCR. The detected $\mathrm{N}_{2} \mathrm{O}$ formation in our simulations was mainly related to $\mathrm{HC}-\mathrm{SCR}$ on PtRh/LNT in lean side because of the reactive propene, which was the only hydrocarbon in our feed gas. In real exhaust gas, the $\mathrm{HC}$ fraction active for HC-SCR is very low and $\mathrm{N}_{2} \mathrm{O}$ will be much lower.

In a developed concept and simulation, air was injected between LNT and SCR to keep the SCR unit in lean side during LNT regeneration. As a consequence, SCR reactions were promoted by oxygen also during enrichments, when the main $\mathrm{NH}_{3}$ formation occurs. The main benefit of the air addition was the improved $\mathrm{NO}_{\mathrm{x}}$ reduction selectivity to $\mathrm{N}_{2}$ with low $\mathrm{NH}_{3}$ emissions in the final exhaust gas.

\section{Acknowledgments}

The author is grateful to the funding of EU in the Powerful research project, to the project partners in Volkswagen, FEV and VKA and all persons, who know to have their contribution in this study in Dinex Ecocat.

\section{References}

[1] Johnson T.: Vehicular Emissions in Review. SAE Int. J. Engines 2014 (3) Nr 7, SAE Paper 2014-01-1491.

[2] Guo G., Dobson D., Warner J., Ruona W., Lambert C.: Advanced Urea SCR System Study with a Light Duty Diesel Vehicle. SAE Technical Paper 2012-01-0371.

[3] Ramsbottom M., Birkby N., Khadiya N., Beesley S.: Development of a thermal enhancer ${ }^{\mathrm{TM}}$ for combined partial range burning and hydrocarbon dosing on medium and heavy duty engine applications. SAE Technical Paper 2011-01-0298.

[4] Gandhi H., Cavataio J., Hammerle R., Cheng Y.: Catalyst system for the reduction of $\mathrm{NO}_{\mathrm{x}}$ and $\mathrm{NH}_{3}$ emissions. US Pat. 2011/0005200, filed 2004.

[5] Snow R., Cavatatio G., Dobson D., Minttreuil C., Hammerle R.,:Calibration of a LNT + SCR diesel aftertreatment system. SAE Technical Paper 2007-01-1244.

[6] Chen H-Y., Weigert E.C., Fedeyko J.M., Cox J.P., Andersen P.J.: Advanced catalysts for combined (NAC + SCR) emission control systems. SAE Technical Paper 2010-01-0302.

[7] Nanjundaswamy H., Tomazic D., Severin C., Kolbeck A., Korfer T., Wittka T., Schnorbu T.: Further improvements of conventional diesel $\mathrm{NO}_{x}$ aftertreatment concepts as pathways for SULEV. DEER Conference, 5 Oct 2011, Detroit.

[8] Maunula T.: Intensification of catalytic aftertreatment systems for mobile applications. SAE Technical Paper 2013-01-0513.

[9] Maunula T.: $\mathrm{NO}_{\mathrm{x}}$ reduction with the combination of LNT and SCR in diesel applications. SAE Int. J. Mater. Manuf., 2014 (7), SAE Technical Paper 2013-24-0161.

[10] Maunula T., Vakkilainen A., Heikkinen R., Härkönen M.,:NO storage and reduction on differentiated chemistry catalysts for lean gasoline applications. SAE Technical Paper 2001-013665 .

[11] Maunula T., Savimäki A., Viitanen A., Kinnunen T., Kanniainen K.: Thermally durable vanadium-SCR catalysts for diesel applications. SAE Technical Paper 2013-01-0796.

[12] Wittka T., Holderbaum B., Maunula T., Weissner M.: Development and demonstration of LNT + SCR system for passenger car diesel application. SAE Int. J. Engines 7(2014), Nr 3, SAE Technical Paper 2014-01-1537.

[13] Prikhodko V.Y., Parks J.E., Pihl J.A., Toops T.J.: Ammonia generation over TWC for passive SCR $\mathrm{NO}_{x}$ control for lean gasoline engines. SAE Technical Paper 2014-01-1505.

[14] Breen J.P., Burch R., Lingaiah N.: An investigation of catalysts for the on board synthesis of $\mathrm{NH}_{3}$. A possible route to low temperature $\mathrm{NO}_{x}$ reduction for lean-burn engines. Catal. Lett., 79 (2002), Nr 1-4, 171.

[15] Koci P., Kubicek M., Marek M., Maunula T., Härkönen M.: Modelling of catalytic monolith converters with low- and high temperature $\mathrm{NO}_{\mathrm{x}}$ storage compounds and differentiated washcoat. Chem. Eng. J. 97, 131-139, 2004.

[16] Chatterjee D., Koci P., Schmeisser V., Marek M., Weibel M.: Modelling of $\mathrm{NO}_{\mathrm{x}}$ storage $+\mathrm{SCR}$ exhaust gas aftertreatment system with internal generation of ammonia. SAE Technical Paper 2010-01-0887.

[17] Maunula T., Ahola J., Hamada H.: Reaction Mechanism and Kinetics of NO Reduction by Propene on Co/Alumina Catalysts in Lean Conditions. Appl. Catal. B 26 (2000) 3, 173-192.

Teuvo Maunula, DEng - Dinex Ecocat Oy, Catalyst development, Typpitie 1, FI-90620 Oulu, Finland.

e-mail:tma@dinex.fi

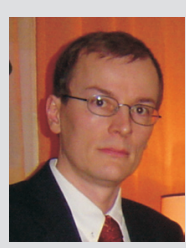

